\title{
Recent perspective of herbicide: Review of demand and adoption in world agriculture
}

\author{
M. M. Hossain \\ Department of Agronomy, Bangladesh Agricultural University, Mymensingh-2202, Bangladesh \\ E-mail: mmhshakil@yahoo.com
}

\begin{abstract}
The demand of herbicide in agriculture is going to be increased and its use is increasingly being adopted around the world. Many developing countries like India, China, Bangladesh are facing shortages of workers for hand weeding crop fields as millions of people are moving to urban from rural areas. In these countries, herbicides are cheaper and more readily available than labor for hand weeding. It is inevitable that, herbicide use will increase in world agriculture, not only because millions of people are leaving rural areas, creating shortages of hand weeders, but also the need to increase crop yields. Hand weeding has never been a very efficient method of weed control often performed too late and not frequently enough. In many parts of the world, herbicides are being increasingly used to replace tillage in order to improve environmental conditions. In comparison with tillage, herbicide use reduces erosion, fuel use, greenhouse gas emissions and nutrient run-off and conserves water. This review article focuses on the status of using herbicides and its adoption in global agriculture.
\end{abstract}

Keywords: Herbicide, Agriculture, Yield

\section{Introduction}

The use of herbicides is increasing in worldwide crop production. The value of the worldwide herbicide market grew by 39\% between 2002 and 2011 and is projected to grow by another $11 \%$ by 2016 (Philips McDougall, 2013). Herbicides are being rapidly adopted in developing countries that face shortages of hand weeding labor and the need to raise crop yields (Zhang, 2003). Improved weed control with herbicides has the potential greatly to improve crop yields in many developing countries in the near future (Masthan et al, 1989). Increased herbicide use promotes fertilizer use, which leads to even greater yield increases (Manda, 2011). Research has shown that, if enough hand weeding is done at the optimal times, crop yields are not reduced by weed competition (Prasad et al., 2008). In reality, crop fields are seldom adequately weeded by hand; weeding is tedious and time consuming. Laborers are not always available when needed (De Datta and Barker, 1997). Weeding is often done late, causing drastic losses in yield (Rashid et al., 2012) The use of herbicides has gained impetus from the general rise in farm wages as a consequence of overall economic growth and growth in non-farm employment opportunities, particularly in Asia adequate non-chemical controls for weeds are not available, and herbicide use is increasing dramatically as a result of rising opportunity costs of labor across the developing world (Pingali and Gerpacio, 1997).

Herbicide use is increasing in many countries where tillage and flooding for weed control are being reduced in order to conserve natural resources: soil, water and energy. Reduced tillage dramatically reduces direct fuel consumption relative to conventional tillage with the moldboard plow. Not only does one herbicide application substitute for several tillage trips, tillage equipment is also heavier than herbicide sprayers and needs more energy to pull steel implements through the soil. A moldboard plow consumes 17 times more diesel fuel per unit area than a herbicide sprayer. A row-crop cultivator requires 4 times more fuel per trip across a field than a herbicide sprayer (Hanna, 2001). Using of herbicides is more beneficial for controlling weeds and the world is rushing to adopt herbicides for the upcoming developed agriculture. Considering the above facts, the objective of this review article was to clarify the future fate of herbicides with the special reference of adoption and its demand in different parts of the world.

\section{Materials and Methods}

The data reported in this review paper are based upon the previous works on herbicides use, sum up of different scientific articles and research works published in different journals, conferences and workshops of the world. 


\section{Results and Discussion}

\section{Herbicides adoption in developed countries}

Herbicides were rapidly adopted in western European countries, the United States, Canada, South Korea and Japan in the 1950s-1970s. As these countries rapidly industrialized, millions of farmworkers left rural areas, which created shortages of workers for hand weeding and tillage operations. Without herbicides to replace the departing workers, it is not likely that widespread crop production would have been practiced any longer in Germany (Koch, 1992). In Japan, herbicide adoption reduced the amount of time required for weeding operations by $97 \%$ (Takeshita and Noritake, 2001). In Korea, manual weeding had been the prevalent control for centuries. As labor shortages appeared, herbicide use was recommended, and by $1971,27 \%$ of the rice hectares were treated (Wang, 1971). By 1977, 65\% of the total rice area was treated with herbicides, and since the 1980 s, $100 \%$ of Korea's rice hectares have been treated with herbicides (Kim, 1981).

In the United States, increased herbicide use accounted for $20 \%$ of the increase in corn yields and $62 \%$ of the increase in soybean yields from 1964 to 1979 (Schroder et al, 1984). Herbicides have been identified as the main factor underlying the increased wheat yield in Canada since the 1960s (Freyman et al, 1982). This control resulted not only in reduced competition from weeds but also in better seedbed moisture because less cultivation was needed. Crop production on the Canadian prairies is limited mainly by lack of water. Taking land out of crop production for a year (fallowing) to conserve water has been practiced for many years. The 1970s marked the introduction of glyphosate; this herbicide transformed grain production in western Canada as it facilitated the widespread adoption of minimum-till and zero-till farming systems (Holm and Johnson, 2010). These systems have reduced fuel and labor costs and have significantly increased soil and water conservation in the semi-arid prairies. The increased cost of diesel fuel and reduced price of glyphosate in Canada in the 1980s-1990s spurred the adoption of no-till. Direct seeding (conservation tillage) practices are now the norm; $70-80 \%$ of the land is direct seeded in western Canada. Greater moisture conservation has facilitated a 70\% reduction in fallow (Blackshaw, 2006). Herbicides have made these changes possible. Australian grain growers have been reducing their use of cultivation since the 1970s, with 44\% of the nation's crop in no-till by 2001 (D'Emden and Llewellyn, 2006). The falling price of the predominant knockdown herbicide, glyphosate, had a significantly positive effect on the adoption of no-till, with 78\% of farmers practicing no-till in 2008 (Llewellyn and D'Emden, 2009). Research demonstrated that using herbicides instead of tillage resulted in $27 \mathrm{~mm}$ of extra water in the soil profile and an increase in grain yields of $15-25 \%$ (Wylie, 2008). In a wheat-fallow system in semi-arid subtropical Queensland, Australia, practicing zero tillage reduced fossil fuel emissions from machinery operation by 2.2 million g CO ha ${ }^{-1}$ over 33 years, or by $67 \mathrm{~kg} \mathrm{CO}^{-1}$ year $^{-1}$ (4-5 tillage operations with a chisel plow to $10 \mathrm{~cm}$ during fallow each year were replaced by one herbicide spray) (Ortiz-Monasterio et al., 2010).

Norway has determined that an absolute prerequisite for the success of these alternative tillage systems is that perennial weeds, as well as some winter-hardy annuals, are removed by spraying herbicides (Riley, 2006). In Finland, in the 1990s, plowing was still the standard practice in spring cereal fields, while the latest statistics show that only half of the cereal field area is currently plowed. At the same time, the sales of glyphosate have more than doubled within a decade in Finland (Salonen, 2012).

\section{Herbicides adoption in Asia}

In the Philippines, the proportion of rice farmers using herbicides increased from $14 \%$ in 1966 to $61 \%$ in 1974 (De Datta and Barker, 1997). Today, 96-98\% of Philippine rice farmers use herbicides (Marsh, 2009). A recent study determined that, with increased labor cost, herbicide application in rice fields is superior to manual weeding even at the lowest weed density by \$US 25-54 ha. At the highest weed density and highest labor cost, herbicide application is approximately 80\% (about \$US 200 per ha) more profitable than hand weeding (Beltran et al., 2012).

In Bangladesh, the loss in rice yield in farmers' fields as a result of poor weeds control has been determined to be 43-51\% (Rashid et al., 2012). The yield gap between herbicide use and hand weeding is as high as 1 metric tha ${ }^{-1}$, with $30 \%$ of farmers losing in excess of $500 \mathrm{~kg} \mathrm{ha}^{-1}$ in the absence of herbicides 
(Ahmed et al., 2001). In Bangladesh, pre-emergence herbicides in rice are 38-46\% cheaper than one hand weeding (Mazid et al., 2001). Economic analysis of rice production in Bangladesh revealed that net income from herbicide application was $116 \%$ higher than hand weeding owing to increased yield and lower cost (Rashid et al., 2012).

With the introduction of higher-yielding varieties of wheat responsive to intensive irrigation and fertilizer application, wheat production in India and Pakistan increased dramatically. Weed infestation is the main cause of low wheat yields in Pakistan and India and is reported to reduce wheat production by 25-30\% (Banga et al., 2003). Traditionally, weeds were controlled in wheat with two hand weedings at an interval of 2 weeks. However, hand weeding schedules have become impossible owing to the high cost and scarcity of labor (Gautam, 2001). Hence, the use of herbicides in wheat is the only acceptable way for effective weed management in wheat (Ashiq et al., 2006). Recent studies showed that herbicide treatment gave $87-90 \%$ weed control, with a consequent $19-21 \%$ increase in grain yield (Khan et al., 2005).

Until recently in India, herbicides were used on $10 \%$ of the wheat hectares to control grass weed species and on $20-25 \%$ of the hectares to control broadleaf species (Chatrath, 2006). Since 2005, the value of the herbicide market in India has doubled (Philips, 2013). The Indian market for herbicides is expected to grow about 40\% annually over the next 5 years (Frabotta, 2011).

About 1 billion person-days of labor would be required to hand weed China's rice fields adequately (Moody, 1991). However, since the late 1970s, rapid expansion of industries has caused an outflow of the farming population as well as a corresponding increase in wages, making herbicide use more attractive to farmers (Zhang, 2003). From 1978 to 1990, with encouragement and promotion from the research and extension sectors, an increasing number of Chinese farmers began to adopt herbicides to control weeds (Zhang et al., 2007). The herbicide application areas of crop fields have steadily increased from less than 1 million ha in the early 1970s to more than 70 million ha in 2005 (Zhang, 2003). In 1973 in China, it was estimated that rice crop losses due to weeds were $40 \%$, even though the crop was hand weeded several times. In 1988, with increased adoption of herbicides, the loss of rice to weeds was estimated to be $6-8 \%$ (Moody, 1991). Current yield losses of rice to uncontrolled weeds above the canopy was $2.8 \%$, while below the canopy uncontrolled weeds resulted in a $1.5 \%$ yield loss (considered separately). The researchers noted that the weed loss estimates were considerably lower than earlier estimates and cited the adoption of herbicides as a cause (Dong et al., 2010).

Traditionally, manual hand weeding has been the predominant method of weed control used by maize farmers in Asia (Shad et al., 1993). If performed with enough frequency and at the right times, hand weeding results in maize yields that are equivalent to yields with herbicides (Prasad et al., 2008). However, because of the shortage of labor and frequent monsoon rains during the early growth period of maize, hand weeding is often delayed or neglected altogether (Prasad et al., 2008). As a result, severe uncontrolled weed infestations have been identified as one of the major reasons for low maize yields in Asia (Hussain et al., 2010). In the Philippines, actual losses due to weeds in maize fields have been reported at 15-30\% (Paller et al., 2001). In India, 39 trials compared maize yields with herbicides to yields obtained with weed control methods; the maize yields with herbicides were 19\% higher (Masthan et al., 1989).

In China, the inability to weed on time has been identified as a major reason for the loss in maize yields in nine out of 12 villages (Meng, 2006). In India, research demonstrated that herbicide treatments in maize produced 83\% more yield in comparison with the practice of plowing the fields to remove weeds (Tareen et al., 1991). In Pakistan, maize yield losses due to weeds have been estimated at 14\% (Sohai et al., 1993). In India, weeds are ranked as the worst production constraint by maize farmers, and herbicides are not used (Joshi et al., 2005). Weeds are more problematic in the dry system because they are not controlled by flooding. A variety of herbicides have been screened and found to be effective for burn down, pre-emergence and post-emergence control in dry-seeded systems. Virtually all rice farmers who practice direct seeding adopt herbicides (Mazid et al., 2006; Ho, 1996). 


\section{Herbicides adoption in Europe}

In Russia, herbicide use led to a 50\% increase in cereal yield on state farms (Chenkin, 1975). Herbicide use in Russia rose from 25 million ha in 1968 to 47 million ha in 1973 (Keiserukhshy and Kashirsky, 1975). The reduced use of herbicides was a major factor resulting in lower wheat production in Russia in the 1990s. The annual loss of Russian cereal production as a result of weed infestation in 1996-2000 was estimated to be 10.5 million tons (Zakharenko, 2004). Losses in the 1990s would have been greater had farmers been unable to use herbicides altogether. Estimates by the Russian Academy of Agricultural Sciences for 1990-1999 were that the additional yield on the 15 million ha treated with herbicides was 6 million tons year (Zakharenko, 2000). Measures aimed at suppressing weeds were identified as the foremost priority for improving cereal production in Russia (Zakharenko, 2004). In recent years, the Russian government has introduced policies to increase the availability and use of herbicides in crop production. The herbicide market in Russia in 2010 was valued 2.8 times higher than in 2003 (Philips, 20113).

In the Ukraine in the early 2000s, increasing weed infestation in crops was identified as one of the main problems causing severe yield losses (Borona et al., 2002). In 2002, only about $50 \%$ of the maize area in the Ukraine was treated with herbicides; by 2012, the herbicide-treated maize area in the Ukraine had risen to 90\% (Brookes and Blume, 2012).

In Kazakhstan, approximately 2.5 million ha of grain are heavily infested with weeds. Government subsidies for herbicide purchase of \$US 2-3 million year resulted in herbicide use on 1.4 million ha. Weed infestation has decreased by about $15 \%$ every year since the weed-control campaign was launched (Lindeman, 2013). Sales of herbicides in Poland in terms of volume were 3 times higher in 2008 than in 2003 (Matyjaszczyk, 2011).

\section{Herbicide adoption in Africa}

In Africa, yield losses in farmers' fields range from $25 \%$ to total crop failure because farmers are unable to perform the necessary weedings at the optimal time. Africa estimates that 2.3 million $t$ of rice is lost annually as a result of weed infestations (15\% of the total potential production) (Rodenburg and Demont, 2009). The failure of farmers to replicate the weed control practices of the research farms is a major cause of low maize yields in Africa. Shortages of labor early in the season results in delayed weeding and subsequent maize yield losses of $15-90 \%$ due to weed competition (Kibata et al., 2002). In Nigeria, maize farmers' weeding practice (one weeding) resulted in a $42 \%$ yield loss in comparison with fields weeded 3 times (Chikoye et al., 2004). The spraying of herbicides to remove weeds from maize fields is an alternative to hand weeding African fields. Smallholder farmers in Africa generally do not use herbicides, and adoption rates are less than 5\% (Overfield et al, 2001; Mavudzi et al., 2001). Although herbicides have been extensively studied in Africa, there was no mechanism to disseminate the technology to smallholders once the research process was over.

Maize yields doubled in Nigeria when atrazine was used (Benson, 1982). In Zimbabwe, research with herbicides resulted in yield increases of up to $50 \%$ in maize (Chivinge, 1990). Use of herbicides in Kenyan weed trials resulted in 33\% higher maize yields than with the farmer practice of hand weeding on account of better weed control (Muthamia et al., 2001).

The adoption of herbicides in African maize fields is likely to lead to increased production not only as a result of improved weed. By controlling the weed with herbicides, maize farmers will be more likely to use fertilizers for even greater maize yield increase (Manda, 2011). African farmers often plant only $50 \%$ of their available fields to crops, leaving the remaining area fallow, because they make a determination that not enough labor would be available to weed the additional fields (Bishop-Sambrook, 2003). By greatly reducing the amount of labor required for weeding, the adoption of herbicides can lead to a greater area planted to crops. Because of high labor costs, hand weeding is no longer considered sustainable for African agriculture, and organizations such as the International Institute for Tropical Agriculture (IITA) are recommending the use of herbicides (Kamara, 2012). In some African countries, such as Mali, herbicide use has doubled in the past 5 years (Foltz, 2010). Weeds controlled by herbicides instead of conventional tillage, stored soil water are increased by $85 \mathrm{~mm}$ in Africa (Mrabet, 2007). 


\section{Herbicide adoption in Latin America}

The primary cause of the expansion of production and economic viability of soybean and maize in Argentina was the widespread adoption of herbicides (particularly glyphosate) for weed control. The widespread adoption of glyphosate in Argentina was in large part due to the almost total adoption of glyphosate-resistant soybeans (Penna and Lema, 2003). Rapid adoption of glyphosate-resistant soybeans occurred in Brazil, Uruguay and Paraguay (Cerdeira et al., 2011). The increased use of glyphosate facilitated the rapid adoption of no-till crop production, reversing decades of destructive farming practices and leading to higher crop yields, economic viability and expansion of planted acres. Effective, inexpensive herbicides made the no-till system viable in Argentina.

The adoption of zero-till systems in southern Brazil remained erratic throughout the 1970s owing mainly to the lack of suitable techniques to control weeds effectively and the lack of planters to work with the high volume of residues. The release of glyphosate in Brazil in the mid-1970s changed this situation by providing effective weed control without the need for tillage (Bolliger et al., 2006). The rural population of Brazil decreased from 64\% of the total population in 1950 to $32 \%$ in 1980 and $16 \%$ in 2010 (Cerri et al., 2010). As a result, there were fewer workers in rural areas to do the work of weeding by hand or with tractors. The substitution of herbicides for hand weeding, plowing and harrowing reduced the need for labor in maize by $38 \%$ (Ribeiro et al., 2007).

\section{Comparison of herbicides adoption}

Rate of adoption of herbicides is highest in developed countries which occupies $36 \%$ of the world consumption. Latin American countries consume $27 \%$ of the world while European region adopted $17 \%$ globally. Adoption is $13 \%$ in Asian countries while African continents are going to be adopted herbicides in their agriculture (Fig. 1) (WAP, 2014).

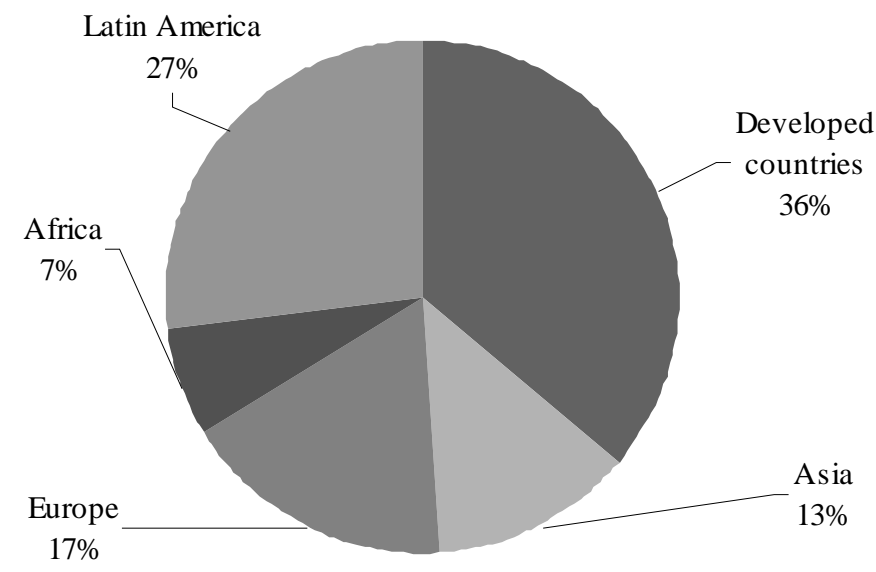

Fig. 1. Herbicides consumption in different continents of the world

\section{Trends of herbicide adoption in developed and developing countries}

The world is rushing towards adopting herbicide to manage weeds in agricultural crop production. Benefits of herbicides over conventional weeding practice forced developed countries to consume $90 \%$, Latin America 70\%, Europe 67\%, Asia 84\% and Africa 94\% more herbicides after 15 years of initiation (Fig. 2) (WAP, 2014).

\section{Trends of herbicide consumption in the world and its expenditure}

Annual usage of herbicides in the world was about 4000 million pounds in the 1953's, increasing to nearly 121000 million pounds at the end of 2013 (WAP, 2014). Since then, at the end of each five years $15-24 \%$ increment occurred (Fig. 3). The herbicide industry is quite significant in dollar terms. Annual expenditures by users of herbicide totaled about \$US33 billion in 1953 and \$US 998 at the end of 2013 (Fig. 4). It is clear from the figure that, there is a sharp increasing trend in consuming herbicides which triggers to increase the market expenditure for herbicides. In future, by the end of 2025 , it is supposed the herbicides consumption to be increased by 150000 million pounds which will costs around \$US 2000. 


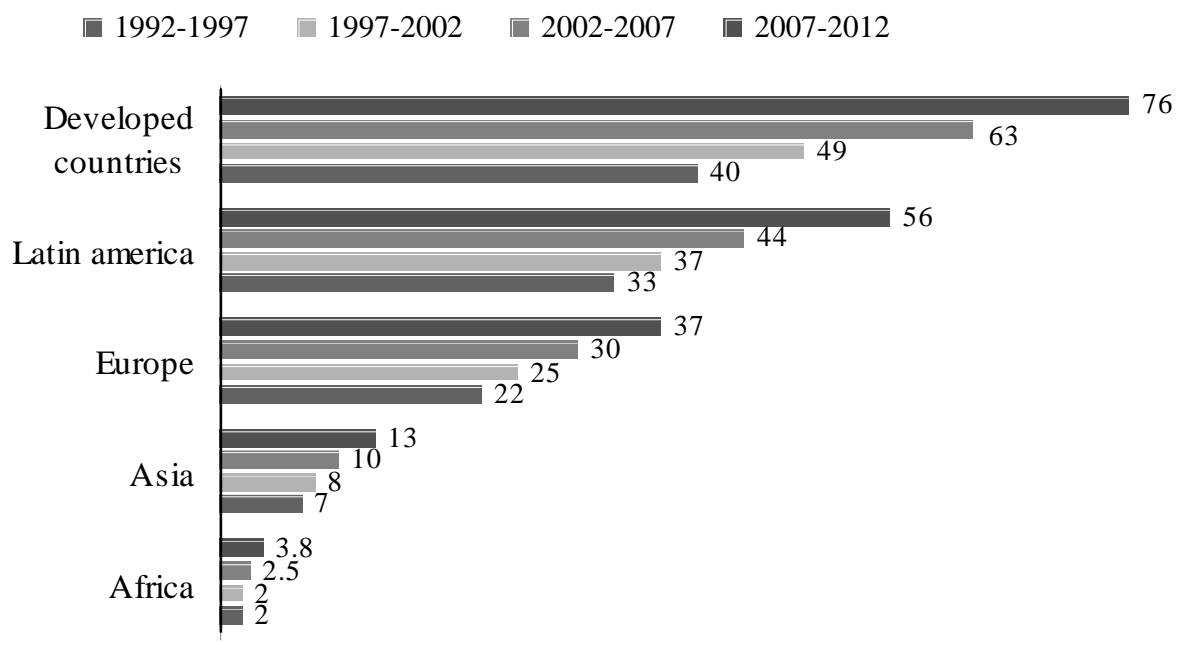

Fig.2: Trend of herbicid adoption in differnt continent (Million Pound)
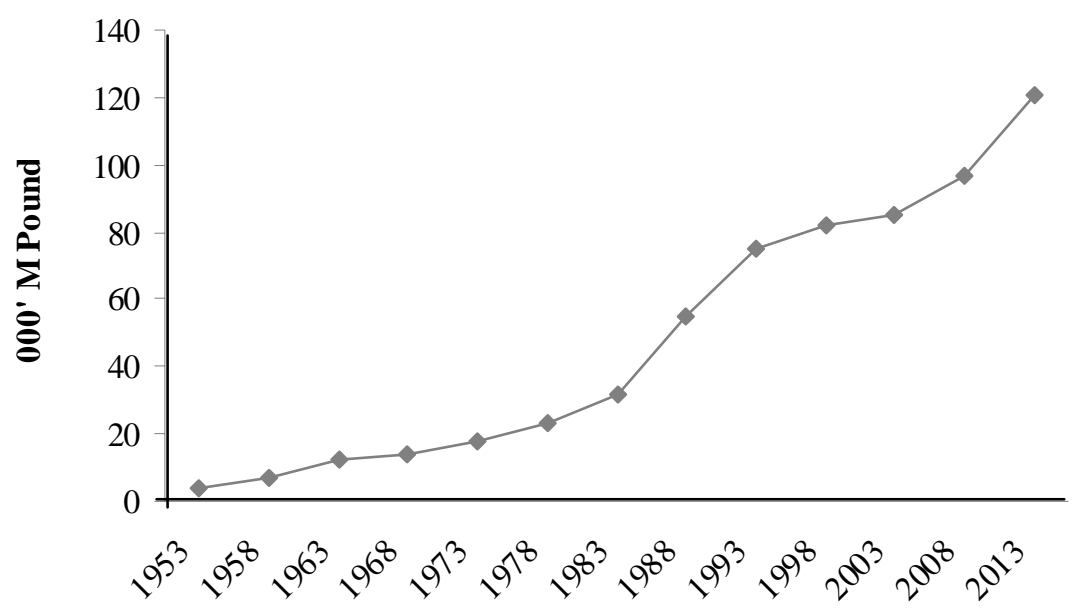

Year (five year endns)

Fig. 3. Trend in herbicide consumption during 1953-2013

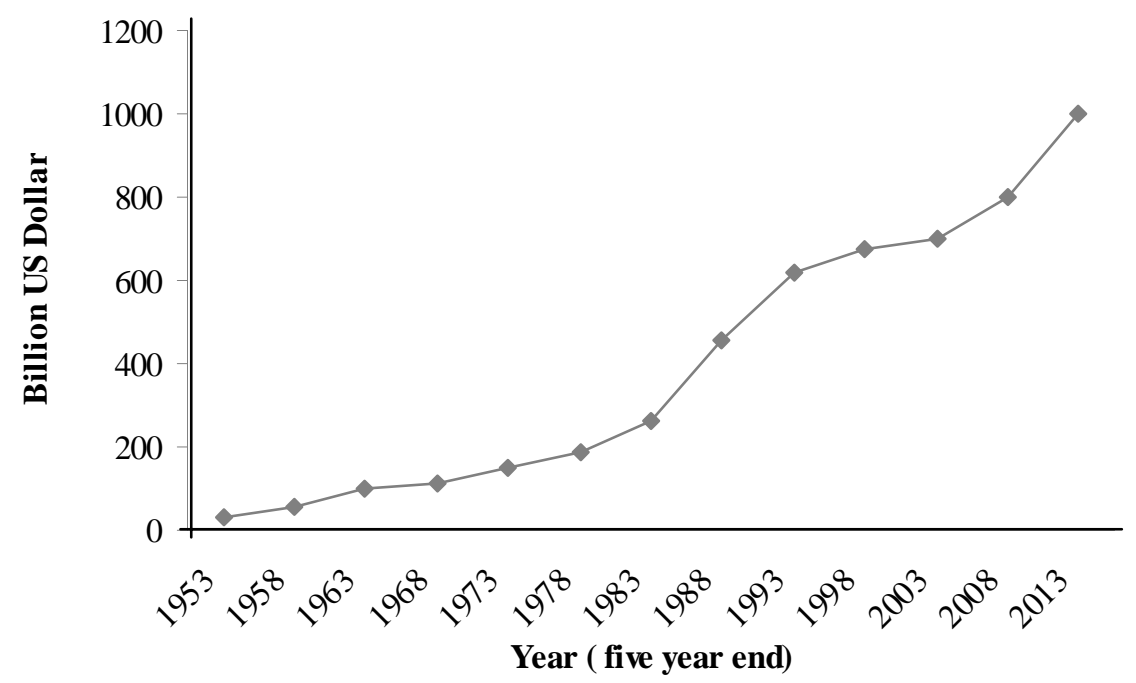

Fig. 4. Trend in expenses for herbicide consumption during 1953-2013 


\section{Crop yield response to herbicides}

Weed control using herbicides increase the crop yield over manual weeding (Hossain et al., 2014a). Different researchers worldwide opined the beneficial effect of herbicides on crop yield resulted not only in reduced competition from weeds but also in better seedbed moisture because less cultivation was needed consequently through improving the soil nutrient status, nutrient uptake by the plants. Yield increment of different crops through herbicidal weed control has been presented in Table 1.

Table 1. Yield increment in different crops through herbicidal weed control

\begin{tabular}{|c|c|c|c|}
\hline \multirow{2}{*}{ Region } & Crops & $\begin{array}{c}\text { Percent yield increment } \\
\text { over manual weeding }\end{array}$ & Reported by \\
\hline \multirow{2}{*}{ United States } & Corn & 20 & \multirow{2}{*}{ Schroder et al., 1984} \\
\cline { 2 - 4 } & Soybean & 62 & Freyman et al., 1982 \\
\hline Canada & Wheat & 32 & Wylie, 2008 \\
\hline Australia & Rice & $15-25$ & Ahmed et al., 2001 \\
\hline \multirow{2}{*}{ Bangladesh } & Rice & 33 & Hossain et al., 2014a \\
\cline { 2 - 4 } & Mustard & 55 & Khan et al., 2014b \\
\cline { 2 - 4 } & Wheat & 42 & Masthan et al., 1989 \\
\hline Pakistan & Wheat & $19-21$ & Tareen et al., 1991 \\
\hline India & Maize & 19 & Chenkin, 1975 \\
\hline Russia & Cereal grains & 53 & Benson, 1982 \\
\hline Zigeria & Maize & 50 & Chivinge, 1990 \\
\hline Zimbabwe & Maize & 50 & Manda, 2011 \\
\hline
\end{tabular}

\section{Limitations of herbicides use}

Herbicides should be applied at recommended rates, as specified on the label. Over-application occurs when a higher than recommended rate of herbicide is applied. Herbicide residues on previously sprayed stubble and other trash can damage emerging crop seedlings upon contact. If animals are given feed that contains certain herbicide residues, their manure can contain these residues. The application of many herbicides is recommended within precisely-defined stages of the crop's growth. Failing to make the application at the proper stage may result in plant damage. Correct application timings are outlined on the label. Pre-harvest intervals, as listed on the label, give the required time after application to harvest the crop. Some crop cultivars are more sensitive than other cultivars to particular herbicides. Incompatible tank mixes can be damaging to crops and not all herbicides can be mixed together. Label instructions should always be followed.

Some important environmental effects are associated with the over use of herbicides. These include unintended damage occurring both on the sprayed site, and offsite. For example, by changing the vegetation of treated sites, herbicide use also changes the habitat of animals such as mammals and birds. This is especially true of herbicides use in forestry, because biodiverse, semi-natural habitats are involved. This is an indirect effect of herbicide use, because it does not involve toxicity caused to the animal by the herbicide. Nevertheless, the effects can be severe for some species. Often there is drift of herbicide beyond the intended spray site, and unintended, offsite damages may be caused to vegetation. There are also concerns about the toxicity of some herbicides, which may affect people using these chemicals during the course of their occupation (i.e., when spraying), people indirectly exposed through drift or residues on food, and wildlife.

An important problem with applications is that non-selective herbicides affect many plants and animals that are not weed the intended target of the treatment. This is especially true of herbicides, because they are toxic to a wide variety of plant species, and not just the weeds. Therefore, the broadcast spraying of herbicides results in broad exposures of non-pest species, which can cause an unintended but substantial mortality of non-target plants. For example, only a few species of plants in any agricultural field or forestry plantation are abundant enough to significantly interfere with the productivity of crop plants. Only these competitive plants are weeds, and these are the only target of a herbicide application. However, there are many other, non-pest species of plants in the field or plantation that do not interfere with the growth of the crop plants, and these are also affected by the herbicide, but not to any benefit in terms of vegetation management. In fact, especially in forestry, the non-target plants may be beneficial, by providing food and habitat for animals, and helping to prevent erosion and leaching of nutrients. 
Most herbicides are specifically plant poisons, and are not very toxic to animals. However, by inducing large changes in vegetation, herbicides can indirectly affect populations of birds, mammals, insects, and other animals through changes in the nature of their habitat. For example, studies in Britain suggest that since the 1950s, there have been large changes in the populations of some birds that breed on agricultural land. These changes may be partly caused by the extensive use of herbicides, a practice that has changed the species and abundance of non-crop plants in agro-ecosystems. This affects the structure of habitats, the availability of nest sites, the food available to granivorous birds, which mostly eat weed seeds, and the food available for birds that eat arthropods, which rely mainly on non-crop plants for nourishment and habitat. During the time that herbicide use was increasing in Britain, there were also other changes in agricultural practices. These include the elimination of hedgerows from many landscapes, changes in cultivation methodologies, new crop species, increases in the use of insecticides and fungicides, and improved methods of seed cleaning, resulting in fewer weed seeds being sown with crop seed. Still, a common opinion of ecologists studying the large declines of birds, such as the gray partridge (Perdix perdix), is that herbicide use has played a central but indirect role by causing habitat changes, especially by decreasing the abundance of weed seeds and arthropods available as food for the birds.

One result of modern agriculture and its reliance upon herbicides is the emergence of weed populations that are resistant to herbicides. Herbicide resistance is the inherited ability of a plant to survive and reproduce following exposure to a dose of herbicide normally lethal to a wild type. In a plant, resistance may be naturally occurring or induced by such techniques as genetic engineering or selection of variants produced by tissue culture or mutagenesis. All natural weed populations, regardless of the application of any herbicide, may contain individual plants (biotypes) that are resistant to herbicides. There are currently 459 unique cases of herbicide resistant weeds globally, with 246 species (143 dicots and 103 monocots). Weeds have evolved resistance to 22 of the 25 known herbicide sites of action and to 157 different herbicides. Herbicide resistant weeds have been reported in 86 crops in 66 countries (ISHRW, 2015). For example, annual ryegrass (Lolium rigidum) has developed glyphosate resistance in Australia as have localised populations of Awnless Barnyard Grass (Echinola colona) and Liverseed Grass (Urochloa panicoides). These resistant populations have been found in dryland cropping systems that have relied on continuous glyphosate applications as the only method of weed control. A list of world wide herbicide resistant weeds presented in the Table 2.

Table 2. Weed genera with the greatest number of resistant species world wide (Prather et al., 2000)

\begin{tabular}{|l|c|c|}
\hline \multicolumn{1}{|c|}{ Genus } & Common name & Number of occurrences \\
\hline Amaranthus & Pigweed & 22 \\
\hline Chenopodium & Labsquarter & 22 \\
\hline Conyza & Horse weed & 21 \\
\hline Lolium & Raygrass & 17 \\
\hline Setaria & Foxtail & 15 \\
\hline Avena & Wild Oat & 15 \\
\hline Echinochloa & Barnargrass & 13 \\
\hline Alopecurus & Blackgrass & 12 \\
\hline Senecio & Groundsel & 11 \\
\hline Polygonum & knotweed & 2 \\
\hline Solanum & Njight shade & 12 \\
\hline
\end{tabular}

Repeated use of any herbicide will expose weed populations to selection pressure that may lead to an increase in the number of surviving, resistant individuals in the population. As a grower continues to use a particular herbicide without any other herbicide modes of action, or without any other cultural practices, the resistant biotype continues to survive and produce seed. Subsequent populations of the resistant biotype will continue to increase until they are the dominant weed in the field. An Overview of the development of resistance to major herbicide groups has been presented in the Fig. 4. 


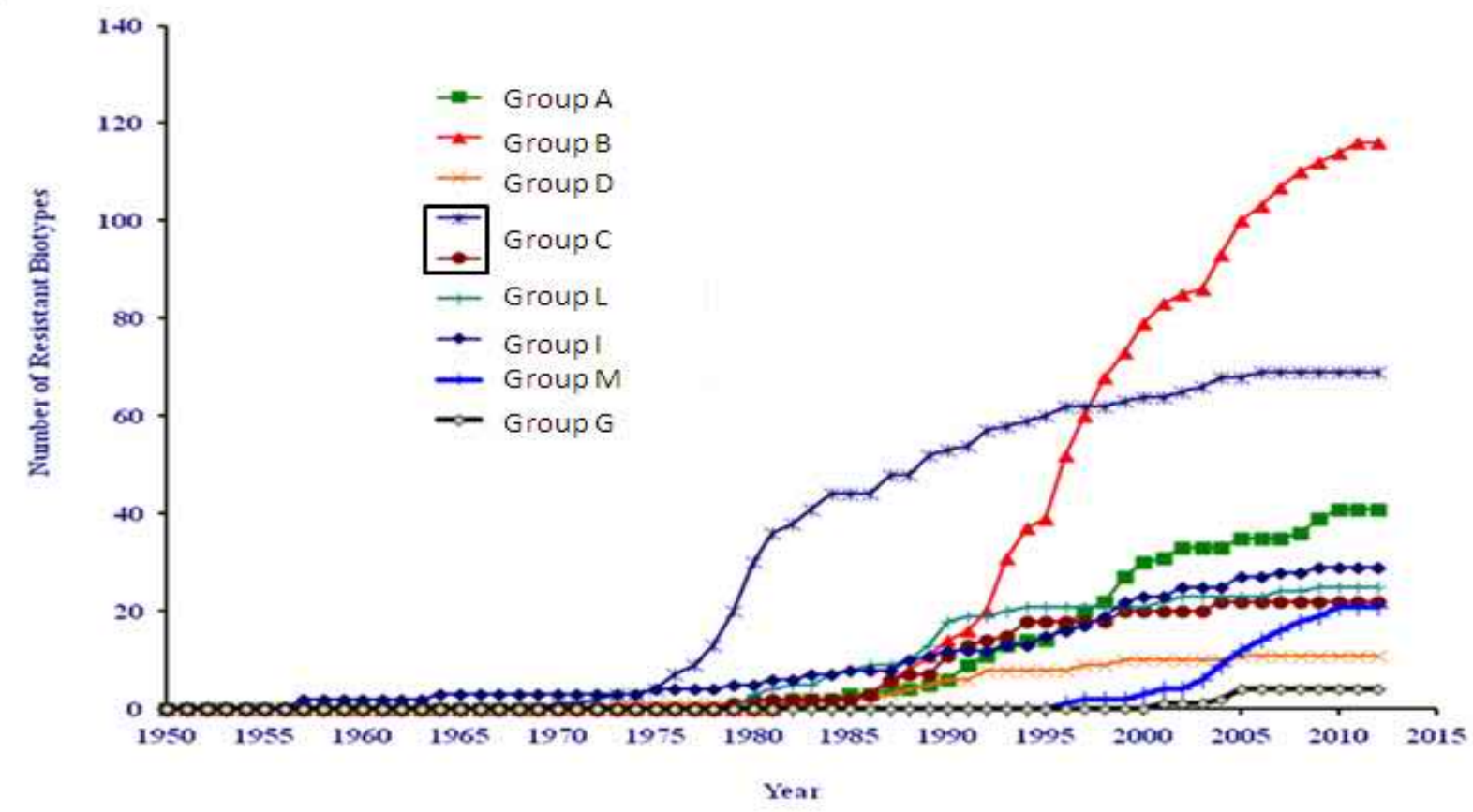

Fig. 04. Overview of the development of resistance to each of the major herbicide groups (ISHRW, 2015)

Weed scientists have found that there are particular weed characteristics that can facilitate development of weed resistance. These include:

- $\quad$ Large amount of seeds produced per plant

- High levels of germination of those seeds

- Several weed flushes per season

- High frequency of resistant genes

Weed scientists have also identified specific common factors that are often present in areas where herbicides resistance has developed:

- Limited or no crop rotation

- Limited or no tillage practices

- A high dependency on herbicides of same modes alone

- Limited use of herbicides with diverse modes

\section{Weed resistance in context}

Farmers have been dealing with the issue of herbicide resistant weeds since the 1950s and it is a reality that growers know how to manage. History demonstrates that growers manage through the occurrence of resistance and that the affected herbicide products continue to be valuable and important. Integrated weed management has been an important part of growing crops where herbicide resistant weeds are present. Managing cropping programs as an ongoing system and planning ahead has allowed farmers to use appropriate weed control methods to effectively manage problem weeds and to reduce the risk of further resistance occurring.

The following general guidelines are the recommendations for minimising the risk of weed resistance:

- Scout fields before and after herbicide applications

- Start with a clean field

- Control weeds early when they are relatively small

- Use the right tool, at the right rate at the right time

- Add other herbicides and cultural practices where appropriate

- Control weed escapes and prevent weeds from setting seeds

- Clean equipment before moving from field to minimise the spread of weed seed. 


\section{Conclusion}

The above stated review results reveals that, weeds have to be controlled for successful crop production. The centuries old practice of hand weeding is no longer sustainable in the modern world. The shortage of workers for hand weeding makes the use of herbicides inevitable throughout the world. Inefficient hand weeding has meant significant yield losses to weeds throughout the world to this day. Significant crop losses due to weeds are simply not acceptable in a world where two billions more people will have to be fed in the next 40 years. Herbicide adoption will significantly increase crop yields and is the key to greater adoption of fertilizer use, which will lead to even greater yields. Herbicides are the key to sustainable crop production throughout the world and will remain the mainstay for weed control for the foreseeable future.

\section{References}

Ahmed, G.J.U., Hassan, M.A., Mridha, A.J., Jabbar, M.A., Riches, C.R., and Robinson, E.J.Z. 2001. Weed management in intensified lowland rice in Bangladesh. Proc. Brighton Crop Protection Conf. Weeds, BCPC, Farnham, Surrey, UK.

Ashiq, M., Muhammad, N. and Ahmad, N. 2006. Comparative efficacy of different herbicides to control grassy weeds in wheat. Pak. J Weed Sci. Res. 12(3):157-161.

Banga, R.S., Yadav, A. and Malik, R.K. 2003. Bio efficacy of flufecacet and sulfo-sulfuron alone and in combination against weed flora in wheat. Indian J Weed Sci. 35(3/4):179-182.

Benson, J.M. 1982. Weeds in tropical crops: review of abstracts on constraints in production caused by weeds in maize, rice, sorghum-millet, groundnuts and cassava. FAO Plant Production and Protection Paper 32 (Suppl. 1).

Beltran, J.C., Pannell, D.J. and Doole, G.J. 2012. Economic implications of herbicide resistance and high labour costs for management of annual barnyard grass in Philippine rice farming systems. Crop Prot. 31:31-39.

Bishop-Sambrook, C. 2003. Labour saving technologies and practices for farming and household activities in Eastern and Southern Africa. IFAD/FAO.

Blackshaw, R. 2006. Evolving on-farm weed management systems: the Canadian experience. 15th Aust. Weeds Conf. 24-28 September, Adelaide, Australia.

Bolliger, A., Magid, J., Amado, T.J.C., Neto, F.S., Ribeiro, M.F.S. and Calegari, A. 2006. Taking stock of the Brazilian 'zero-till revolution': a review of landmark research and farmers' practice. Adv. Agron. 91:48-110.

Borona, V., Zadorozhny, V., Soroka, S., Ramaniuk, R., Hurle, K. and Bulcke, R. 2002. Integrated weed management methods for maize under the conditions of the forest-steppe zone of Ukraine and Byelorussia. 12th Eur Weed Res. Soc. Symp., Wageningen, The Netherlands.

Brookes, G. and Blume, Y. 2012. The potential economic and environmental impact of using current GM traits in Ukraine arable crop production. Institute of Food Biotechnology and Genomics, Kiev, Ukraine.

Cerdeira, A.L., Gazziero, D.L., Duke, S.O. and Matallo, M.B. 2011. Agricultural impacts of glyphosate-resistant soybean cultivation in South America. J. Agric. Food Chem. 59:5799-5807.

Cerri, C.C., Bernoux, M., Maia, S.M.F., Cerri, C.E.P., Junior, C.C. and Feigl, B.J. 2010. Greenhouse gas mitigation options in Brazil for land-use change, livestock and agriculture. Scientia Agricola : 67(1).

Chatrath, R., Mishra, B. and Shoran. 2006. Yield potential survey-India, in International Symposium on Wheat Yield Potential: Challenges to International Wheat Breeding, ed. by Reynolds MP, Pietragalla J and Bran HJ. CIMMYT, El Batán, Mexico.

Chenkin, A.F. 1975. Economic effect of plant protection in the Russian Federated Republic. VIII Int. Congr. on Plant Protection. Vol. 2, Moscow, USSR, pp. 27-31.

Chikoye, D., Schultz, S. and Ekeleme, F. 2004. Evaluation of integrated weed management practices for maize in the Northern Guinea savanna of Nigeria. Crop Prot. 23:895-900.

Chivinge, O.A. 1990. Weed science technological needs for the communal areas of Zimbabwe. Zambezia. 17(2):133-143.

De Datta, S.K. and Barker, R. 1997. Economic evaluation of modern weed control techniques in rice, inIntegrated Control of Weeds, ed. By Fryer, J.D. and Matsunaka, S. University of Tokyo Press, Tokyo, Japan.

D'Emden, F.H. and Llewellyn, R.S. 2006. No-tillage adoption decisions in southern Australian cropping and the role of weed management. Aust. J. Exp. Agric. 46:563-569.

Dong, K., Chen, B., Li, Z., Dong, Y. and Wang, H. 2010. A characterization of rice pests and quantification of yield losses in the japonica rice zone of Yunnan, China. Crop Prot. 29:603-611.

Foltz, J. 2010. Opportunities and investment strategies to improve food security and reduce poverty in Mali through the diffusion of improved agricultural technologies. USAID-Mali AEG Group, 16 June.

Frabotta, D. 2011. India herbicide market to propel to double-digit growth in crop protection value. Farm Chem, Int. 47:2209-2218.

Freyman, S., Palmer, C.J., Hobbs, E.H., Dormaar, J.F., Schaalje, G.B. and Moyer, J.R. 1982. Yield trends on long-term dry land wheat rotations at Lethbridge. Can. J. Plant Sci. 62:609-619. 
Gautam, R.C. 2001 Wheat production assured success in battle against hunger and poverty. Indian Farming October, 2001.

Hanna, M. 2001. Fuel required for field operations. Iowa State University Extension, p. 709.

Ho, N.K. 1996. Current status of rice herbicide use in the tropics. JIRCAS Int. Symp. Ser. 4:77-86.

Hobbs, P.R. and Govaerts, B. 2010. How conservation agriculture can contribute to buffering climate change, in Climate Change and Crop Protection. CABI, Wallingford, Oxon, UK, pp. 177-199.

Holm, F. and Johnson, E. 2010. A brief history of herbicide use in western Canada. $17^{\text {th }}$ Australas Weeds Conf., 26-30 September, 2010. Christchurch, New Zealand.

Hossain, M. M., Begum, M., Rahman, M. M. and Hashem, M. A. 2014a. Weed management in mustard (Brassica napus L.) under minimum tillage and crop residues. Proc. of the Conference on Conservation Agriculture for Smallholders in Asia and Africa. 7-11 December 2014, Mymensingh, Bangladesh.. pp 111-113.

Hossain, M. M., Begum, M., Rahman, M. M. and Hashem, M. A. 2014b. Weed management in wheat (Triticum aestivum L.) under minimum tillage and crop residues. Proc. Conference on Conservation Agriculture for Smallholders in Asia and Africa. 711 December 2014, Mymensingh, Bangladesh. pp 33-35.

Hussain, M., Ali, A., Tahir, M., Waseem, M., Nadeem, M.A. and Butt, A. 2010. Comparative efficacy of new herbicides for weed control in maize (Zea mays L.). Int. J. Trop. Agric. 28(1/2):17-22.

ISHRW (International Survey of Herbicide Resistant Weeds). 2015. Overview of the development of resistance to each of the major herbicide groups (amended for Australian herbicide groups from Dr lan Heap. Available at : http://weedscience.org/

Johnson, D., Mortimer, M., Orr, A. and Riches, C. 2003. Weeds, Rice and Poor People in South Asia. Natural Resources Institute, Chatham, Kent, UK.

Joshi, P.K., Singh, N.P., Singh, N.N., Gerpacio, R.V. and Pingali, P.L. 2005. Maize in India, in Production Systems, Constraints, and Research Priorities. CIMMYT, El Batán, Mexico.

Kamara, A.Y. 2012. Best practices for maize production in the West African savannas. IITA R4D Rev. (9).

Keiserukhshy, M.G. and Kashirsky, O.P. 1975. Economics of plant protection in the USSR. VIII International Congress of Plant Protection. Vol. II.

Khan, A., Ilyas, M. and Hussain, T. 2005. Response of wheat to herbicides application and hand weeding under irrigated and nonirrigated conditions. Pak. J. Weed Sci. Res. 11(1/2):1-9.

Kibata, G.N., Maina, J.M., Thuranira, E.G., Musembi, F.J., Nyanyu. G, Muthamia, J.G.N. 2002. Participatory development of weed management strategies in maize based cropping systems in Kenya.13 $3^{\text {th }}$ Aust., 2002. Weeds Conf., Perth, Australia, pp. 343-344.

Kim, K.U. 1981. Weed control in Korea, in Weeds and Weed Control in Asia. FFTC Book Series No. 20, Taipei, Taiwan.

Koch, W. 1992. Impact of weeds on developing countries. Proc. $1^{\text {st }}$ Int. Weed Control Congr., Melbourne, Australia.

Lindeman, M. 2013. Kazakhstan Wheat Production: an Overview. [Online]. Available:http://www.fas.usda.gov/pecad2/highlights/ 2005/03/Kazakh_Ag/index.htm

Llewellyn, R.S. and D'Emden, F.H. 2009. Adoption of no-till cropping practices in Australian grain growing regions. Grains Research and Development Corporation, Barton, ACT, Australia.

Manda, P. 2011. Evaluation report on the impact of spray service technology uptake on small-scale farmer livelihoods in Zambia. CARE, Zambia.

Marsh, S. 2009. Herbicide use strategies and weed management options in Filipino and Australian cropping. Australian Centre for International Agricultural Research.

Masthan, S.C., Reddy, K.A., Reddy, T.R. and Rao, L.J. 1989. Increasing the productivity of rice, maize and groundnut in farmers' fields in Andhra Pradesh through weed control. Pesticides, 23(6):42-44.

Matyjaszczyk, E. 2011. Selected aspects of plant protection in Poland, five years on from EU accession. Outlook Agric. 40(2):119123.

Mavudzi, Z., Mashingaidze, A.B., Chivinge, O.A., Ellis-Jones, J. and Riches, C. 2001. Improving weed management in a cottonmaize system in the Zambezi Valley, Zimbabwe. Proc. Brighton Crop Protection Conf. Weeds, BCPC, Farnham, Surrey, UK, pp. 169-174.

Mazid, M.A., Jabber, M.A., Riches, C.R. Robinson, E.J.Z., Mortimer, M. and Wade, L.J. 2001. Weed management implications of introducing dry-seeded rice in the Barind Tract of Bangladesh. Proc. Brighton Crop Protection Conf.-Weeds, BCPC, Farnham, Surrey, UK.

Meng, E.C.H., Hu, R., Shi, X. and Zhang, S. 2006. Maize in China, in Production Systems, Constraints, and Research Priorities. CIMMYT, El Batán, Mexico.

Moody, K., Escalada, M.M. and Heong, K.L. 1997. Weed management practices of rice farmers in Iloilo, Philippines, in Pest Management of Rice Farmers in Asia. International Rice Research Institute, Manila, the Philippines.

Moody, K. 1991. Weed management in rice, in Handbook of Pest Management in Agriculture, Vol. 3, ed. by Pimentel, D. CRC Press, Boca Raton, FL, pp. 301-328.

Mrabet, R. 2013. No-Till Research Rainfed Areas in Morocco. [Online]. KASSA (2007). Available: http://kassa.cirad.fr 
Muthamia, J.G.N., Musembi, F., Maina, J.M., Okuro, J.O., Amboga, S. and Muriithi, F. 2001. Participatory on-farm trials on weed control in smallholder farms in maize-based cropping systems. Proc. $7^{\text {th }}$ Eastern and South Africa Regional Maize Conf., Nairobi, Kenya, pp. 468-73.

Ortiz-Monasterio, I., Wassmann, R., Govaerts, B., Hosen, Y., Katayanagi, N. and Verhulst, N. 2010. Greenhouse gas mitigation in the main cereal systems: rice, wheat and maize, in Climate Change and Crop Production. CABI, Wallingford, Oxon, UK.

Overfield, D., Murithi, F.M., Muthamia, J.N., Ouma, J.O., Birungi, K.F. and Maina J.M. 2001. Analysis of the constraints to adoption of herbicides by smallholder maize growers in Kenya and Uganda. Proc. Brighton Crop Protection Conf.-Weeds, BCPC, Farnham, Surrey, UK, pp. 907-912.

Paller, E.C., Ramirez, A.H.M. and Malenab, E.T. 2001. Weed management in grain corn: comparing calendared treatments and use of weed control action indicators (WCAI). Philipp. J. Crop Sci., 27(1):9-12.

Penna, J.A. and Lema, D. 2003. Adoption of herbicide tolerant soybeans in Argentina: an economic analysis, in Economic and Environmental Impacts of Agrotechnology. Kluwer-Plenum, New York, NY, pp.203-220.

Pereira, P.A.A., Martha, G.B., Jr, Santana, C.A.M. and Alves, E. 2012. The development of Brazilian agriculture: future technological challenges and opportunities.Agric Food Security 1:4.

Pingali, P.L. and Gerpacio, R.V. 1997. Towards reduced pesticide use for cereal crops in Asia. CIMMYT Working Paper, 97-04.

Philips McDougall. 2013. [Online]. Available: http://phillipsmcdougall.co

Prasad, A., Singh, G. and Upadhyay, R.K. 2008. Integrated weed management in maize (Zea mays L.) and maize + blackgram. Indian J. Weed Sci., 40(3/4):191-192.

Prateher, T.S. Ditomaso, J.M. and Halt, J.S. 2000. Herbicide resistance: Definition and Management. Available at: http://anrcatalog.ucdavis.edu/

Pretty, J. and Hine, R. 2001. Portraits of Sustainable Agriculture Projects and Initiatives. Centre for Environment and Society, University of Essex.

Rashid, M.H., Alam, M.M. and Ladha, J.K. 2012. Comparative efficacy of pretilachlor and hand weeding in managing weeds and improving the productivity and net income of wet-seeded rice in Bangladesh. Field Crops Res128:17-26.

Ribeiro, M.F.S., Denardin, J.E., Bianchini, A., Ferreira, R., Flores, C.A. and Kliemann, H.J. 2007. Conservation Agriculture Research in Brazil. Deliverable 1.4-Appendix A1. [Online]. KASSA (2007). Available at: http://kassa.cirad.fr /

Rodenburg, J. and Demont, M. 2009. Potential of herbicide resistant rice technologies for sub-Saharan Africa. Ag. Bio-Forum, 12(3/4):313-325.

Riley, H. 2006. Long-term tillage trials on loam and clay soils in SE Norway: yield results for 1998-2004. Nordic Association of Agricultural Scientists. NJF Seminar 3782(4):190-195.

Salonen, J., Hyvonen, T., Kaseva, J. and Jalli, H. 2012. Impact of changed cropping practices on weed occurrence in spring cereals in Finland- a comparison of surveys in 1997-1999 and 2007-2009. Weed Res., 53:110-120.

Savary, S., Willocquet, L., Elazegui, F.A., Castilla, N.P. and Teng, P.S. 2000. Rice pest constraints in tropical Asia: quantification of yield losses due to rice pests in a range of production situations. Plant Dis 84:357-369.

Schroder, D., Headley, J.C. and Finley, R.M. 1984. The contribution of herbicides and other technologies to corn production in the corn belt region 1964-1979. N Cent J. Agric. Econ. pp

Sohail, A., Mahmood, J., Khan, M.H. and Mahmood, M.M. 1993. Evaluation of some insecticides on maize against Chilo partellus (Swinhoe). Pak J. Agric. Res., 14(4):393-395.

Shad, R.A., Chatha, M.Q. and Nawaz, H. 1993. Weed management studies in maize. Pak. J. Agric. Res., 14(1):44-50.

Takeshita, T. and Noritake, K. 2001. Development and promotion of labor saving application technology for paddy herbicides in Japan. Weed Biol. Manag. 1:61-70.

Tareen, M.A.K., Chatha, M.Q., Malik, H.N. and Javed, H.I. 1991. Effect of Primextra herbicide on the productivity of maize grown under medium rain fed conditions. Pak. J. Agric. Res., 12(4):257-263.

Wang, I.K. 1971. Diffusion and acceptance of recommended farm practices for increased food production. College of Agriculture, Seoul National University, Seoul, South Korea.

WAP (World Agricultural Pesticides). 2014. Industry market research for business leaders, strategists, decision makers. Pp. $399-411$

Wylie, P. 2008. High profit farming in Northern Australia. Grains Research and Development Corporation, Barton, ACT, Australia.

Zakharenko, V.A. 2000. Bio-economic methods and decision-making models for herbicide use in Russian agriculture. $3^{\text {rd }}$ Int. Weed Science Congr., Foz do Iguaçu, Paraná, Brazil.

Zakharenko, V.A. 2004. Phytosanitary condition of agro-ecosystems and potential yield losses from harmful organisms in agriculture under conditions of Russia's multiform economy. Russ. Agric. Sci. 5:13-18.

Zhang, C.X., Liu, Y., Cui, H.L., Wei, S.H. and Huang, H.J. 2007. Herbicide usage and associated problems in China. XVI Int. Plant Protection Congr., Glasgow, UK.

Zhang, Z.P. 2003. Development of chemical weed control and integrated weed management in China. Weed Biol. Manag. 3:197203. 